\title{
Assessment of Knowledge Level and Its Determinants amongst Kangayam Cattle Farmers in Vermicomposting
}

\author{
N. V. Kavithaa ${ }^{1 *}$, N. Vimalrajkumar ${ }^{2}$, C. Manivannan ${ }^{3}$ and S. Manokaran ${ }^{4}$ \\ ${ }^{1}$ Kangayam Cattle Research Station, Baguthampalayam, Sathyamangalam - 638 451, India \\ ${ }^{2}$ Department of Veterinary and Animal Husbandry Extension Education, Madras Veterinary \\ College, Chennai - 600 007, India \\ ${ }^{3}$ University Publication Division, TANUVAS, MMC, Chennai-600051, India \\ ${ }^{4}$ Kangayam Cattle Research Station, Baguthampalayam, Sathyamangalam - 638 451, India \\ *Corresponding author
}

\begin{tabular}{|l|}
\hline Ke y w o r d s \\
Vermicomposting, \\
$\begin{array}{l}\text { Knowledge level, } \\
\text { Kangayam cattle }\end{array}$ \\
\hline Article Info \\
\hline $\begin{array}{l}\text { Accepted: } \\
\text { 04 August } 2020 \\
\text { Available Online: } \\
\text { 10 September } 2020\end{array}$ \\
\hline
\end{tabular}

\section{Keywords}

Vermicomposting,

Knowledge level,

Kangayam cattle

\section{Article Info}

Accepted:

Available Online

10 September 2020

\section{A B S T R A C T}

Vermicomposting is a simple biotechnological process of composting, in which certain species of earthworms are used to enhance the process of waste conversion and produce a better end product. A cross sectional study was conducted in Erode and Tirupur districts of Tamil Nadu among randomly selected 120 Kangayam cattle farmers. A semi structured interview schedule was prepared to assess the independent variables and to measure the knowledge level of farmers. The schedule was pretested in order to check the reliability and validity. The data were collected by adopting personal interview method and they were tabulated, analysed with suitable statistical tools. The study revealed that majority of the respondents $(56.67 \%$ ) were middle aged, having small land holding of 2.5 acres to 5 acres of land $(67.50 \%)$ and were primarily agriculturist $(81.67 \%)$. Regarding the experience in Kangayam cattle rearing 35.83 per cent of the respondents had $7-10$ years of experience followed by 28.33 per cent of them had more than 10 years of experience in Kangayam cattle rearing. With related to the psychological variables majority $(61.67 \%)$ of the respondents were of medium level of risk orientation and 57.50 of them are having high level of social participation. It was also found that, about 60.00 per cent of the respondents are had medium level of mass media exposure followed by high level of mass media exposure $(24.17 \%)$. Majority of the respondents $(55.83 \%)$ had medium level of knowledge in various domains of vermicompost technology followed by 31.67 per cent of the respondents are possessing low level of knowledge in vermicompost technology. Only 12.50 per cent of the respondents are having high level of knowledge in vermicomposting. The study also showed that the variables experience in Kangayam cattle rearing and mass media exposure are positively and significantly associated with the level of knowledge at $1 \%$ significant level and the variables viz., age, Kangayam cattle herd size and risk orientation are positively associated with knowledge level at 5\% significant level. Hence, suitable extension programmes should be planned to inculcate the knowledge about the vermicompost technology to increase the compost production in the future farming conditions. 


\section{Introduction}

Indian farmers, like many other agrarian countries, are known to have evolved nature friendly farming systems and practices such as mixed farming, crop rotation, mixed cropping and most importantly using naturally available bio mass as manure in their field. Soon after independence, with escalating population and shrinking resource base, the challenge to increase agricultural production on a sustainable basis is indeed a formidable one to feed the millions. In order to accomplish this, increased usage of chemical fertilizers, which have made the green revolution possible, has not only aggravated multi-nutrient deficiencies in soil plant system but also deteriorated soil health and created environment pollution. (Satya and Dibyanshu, 2012)Moreover, chemical fertilizers are becoming costlier input in agriculture. The aim of modern farming system has to maximize the agricultural production through use of increased quantities of these external inputs without due consideration to their ill effects. Indiscriminate use of chemical fertilizer causes several problems on the field as well as outside it. Over the years chemical fertilisers deteriorate the fertility of soil and now our production is stagnated and many efforts are failed to increase the productivity and leads to health hazards (Kharmale, 2006).

In India almost more than one lakh extension personnel and 45,000 agricultural scientists who are directly or indirectly associated or engaged in the dissemination of innovations among the farming community. In spite of these facts, about 30 to 40 per cent recommendations are being adopted by the farmers. It indicates that our farmers have lack of knowledge and skill of new innovations, thus it necessary to inculcate the farmers and farm women in various aspects of agricultural production.
Vermicomposting is a simple biotechnological process of composting, in which certain species of earthworms are used to enhance the process of waste conversion and produce a better end product. Earthworms are often referred to as farmer's friends and natures ploughmen. Earthworms are extremely important in soil formation, principally through their activities in consuming organic matter, fragmenting and mixing it intimately with mineral particles to form aggregates.

For promoting the use of vermicompost, it is indispensable to hook the attention of farmers towards this technology and encourage them to use it in crop production. For accomplishing this goal, it is essential to assess the existing level of knowledge of farmers in vermicompost technology. With this backdrop, the present study was designed to assess the existing knowledgelevel of farmers in vermicompost technology

\section{Materials and Methods}

A cross sectional study was conducted in Erode and Tirupur districts of Tamil Nadu purposively as these districts are considered as the breeding tract of Kangayam animals. Out of ten revenue taluks in Erode district, two taluks viz., Gobichettipalayam and Sathyamangalam and from the nine taluks of Tirupur district, two viz., Kangayam and Dharapuram taluks were randomly selected for the study. From each of the afore selected four taluks, 30 livestock farmers who were involved in Kangayam cattle rearing, thus a total sample size of 120 Kangayam cattle farmers were randomly selected for the present study.

Keeping in view of the objectives of the study, a semi structured interview schedule was prepared. The interview schedule consists of the information on independent variables 
namely age, education, land holding, experience in Kangayam cattle rearing, annual income, extension contact and source of information. To measure the knowledge level of farmers in this study by using standardized scale developed by Vyas et al., (2014) with slight modification. The scale was consists of 40 knowledge statements these statements are based on nine domains viz., concepts of vermicompost technology, vermibed preparation, raw material, earthworms, water, filling of bed, maintenance of vermibed, harvesting of ready compost and its uses and advantages. The respondent's knowledge was measured on a 3 point continuum viz., know thoroughly, know somewhat and not known with respective weightages of 2,1 and 0 . On the basis of the total score obtained (scores ranged from 80 0 ), respondents were categorized into three classes i.e. low, medium and high level of knowledge. Further, the Knowledge Index was also computed for each knowledge items and the mean knowledge index score was arrived for each of the nine domains.

Knowledge Index for ith item $=\frac{\text { Total Score obtained by ith item }}{\text { Maximum possible score for ith item }} X 100$

The schedule also constituted the information about dependent variable namely knowledge possessed by the farmers upon vermicompost technology and it was pretested in order to check the reliability through test-retest method and validity through content validity. The data were collected by adopting personal interview method and they were tabulated, analysed with suitable statistical tools.

\section{Results and Discussion}

\section{Personal, socio-economic and psychological profile of the selected respondents}

A perusal of Table 1 indicates that, majority of the respondents $(56.67 \%)$ were middle aged, having small land holding of 2.5 acres to 5 acres of land $(67.50 \%)$ and were primarily agriculturist $(81.67 \%)$. Regarding the experience in Kangayam cattle rearing 35.83 per cent of the respondents had $7-10$ years of experience followed by 28.33 per cent of them had more than 10 years of experience in Kangayam cattle rearing. With related to the psychological variables majority $(61.67 \%)$ of the respondents were of medium level of risk orientation and 57.50 of them are having high level of social participation. It was also found that, about 60.00 per cent of the respondents are had medium level of mass media exposure followed by high level of mass media exposure $(24.17 \%)$. The findings are in line with Pagaria (2014) and Lavania and Kumar (2014).

\section{Overall knowledge level of the farmers about Vermicompost technology}

An attempt was made to find out the overall knowledge level of the farmers about vermicompost technology by computing the number of farmers who possessed adequate knowledge innine domains of vermicompost technology and the results of such analysis is given below in Table 2 .

A perusal of Table 2 reveals that majority of the respondents $(55.83 \%)$ had medium level of knowledge in various domains of vermicompost technology followed by 31.67 per cent of the respondents are possessing low level of knowledge in vermicompost technology. Only 12.50 per cent of the respondents are having high level of knowledge in vermicomposting. The trend in this study slopes from medium to low might be due to that the farmers are unaware about the technology of vermicompost.

Table 3 reflects the Pearson's coefficient of correlation of dependent variable Knowledge level with eighteen causal variables. 
Table.1 Personal, socio-economic and psychological profile of the selected respondents

\begin{tabular}{|c|c|c|c|c|}
\hline S.No & Variables & Category & $\begin{array}{c}\text { No. of } \\
\text { respondents } \\
\text { (f) } \\
\end{array}$ & $\begin{array}{c}\text { Percentage } \\
(\%)\end{array}$ \\
\hline \multirow[t]{3}{*}{1} & \multirow[t]{3}{*}{ Age } & Young (less than 35yrs) & 18 & 15.00 \\
\hline & & Middle $(35-45$ yrs $)$ & 68 & 56.67 \\
\hline & & Old (more than 45yrs) & 34 & 28.33 \\
\hline \multirow[t]{3}{*}{2} & \multirow[t]{3}{*}{ Land holding } & Marginal (<2.5 acres $)$ & 24 & 20.00 \\
\hline & & Small (2.5 acres to 5 acres) & 81 & 67.50 \\
\hline & & Large (> 5 acres) & 15 & 12.50 \\
\hline \multirow[t]{3}{*}{3} & \multirow{3}{*}{$\begin{array}{l}\text { Primary } \\
\text { Occupation }\end{array}$} & Agriculture & 98 & 81.67 \\
\hline & & Animal Husbandry & 14 & 11.66 \\
\hline & & $\begin{array}{l}\text { Govt. Service / Private job/ } \\
\text { Business }\end{array}$ & 8 & 6.67 \\
\hline \multirow[t]{4}{*}{4} & \multirow{4}{*}{$\begin{array}{l}\text { Experience in } \\
\text { Kangayam } \\
\text { cattle rearing }\end{array}$} & Less than 5 years & 12 & 10.00 \\
\hline & & $5-7$ years & 31 & 25.83 \\
\hline & & $7-10$ years & 43 & 35.83 \\
\hline & & More than 10 years & 34 & 28.33 \\
\hline \multirow[t]{3}{*}{5} & \multirow{3}{*}{$\begin{array}{l}\text { Kangayam } \\
\text { cattle herd size }\end{array}$} & Small(less than 2 cattle) & 78 & 65.00 \\
\hline & & Medium (2-3 cattle) & 27 & 22.50 \\
\hline & & Large(more than 3 cattle) & 15 & 12.50 \\
\hline \multirow[t]{3}{*}{6} & \multirow[t]{3}{*}{ Risk orientation } & Low & 29 & 24.17 \\
\hline & & Medium & 74 & 61.67 \\
\hline & & High & 17 & 14.17 \\
\hline \multirow[t]{3}{*}{7} & \multirow{3}{*}{$\begin{array}{l}\text { Social } \\
\text { participation }\end{array}$} & Low & 16 & 13.33 \\
\hline & & Medium & 35 & 29.17 \\
\hline & & High & 69 & 57.50 \\
\hline \multirow[t]{3}{*}{8} & \multirow{3}{*}{$\begin{array}{l}\text { Mass Media } \\
\text { exposure }\end{array}$} & Low & 19 & 15.83 \\
\hline & & Medium & 72 & 60.00 \\
\hline & & High & 29 & 24.17 \\
\hline
\end{tabular}

Table.2 Overall knowledge level of the farmers about Vermicompost technology

\begin{tabular}{|c|l|c|c|}
\hline S.No & \multicolumn{1}{|c|}{ Knowledge categories } & Frequency & Percentage \\
& & $(\mathbf{f})$ & $(\%)$ \\
\hline $\mathbf{1}$ & Low (<Mean - 1SD) & 38 & 31.67 \\
\hline $\mathbf{2}$ & Medium \{<Mean - 1SD) to (> Mean + 1SD)\} & 67 & 55.83 \\
\hline $\mathbf{3}$ & High (> Mean + 1SD) & 15 & 12.50 \\
\hline
\end{tabular}


Table.3 Coefficient of correlation of Knowledge level with selected independent variables

\begin{tabular}{|c|l|c|}
\hline S.No & \multicolumn{1}{|c|}{ Variables } & (r) \\
\hline $\mathbf{1}$ & Age $\left(\mathrm{X}_{1}\right)$ & $0.261^{*}$ \\
\hline $\mathbf{2}$ & Land holding $\left(\mathrm{X}_{1}\right)$ & 0.084 \\
\hline $\mathbf{3}$ & Primary Occupation $\left(\mathrm{X}_{1}\right)$ & 0.045 \\
\hline $\mathbf{4}$ & Experience in Kangayam cattle rearing $\left(\mathrm{X}_{1}\right)$ & $0.706^{* *}$ \\
\hline $\mathbf{5}$ & Kangayam cattle herd size $\left(\mathrm{X}_{1}\right)$ & $0.401^{*}$ \\
\hline $\mathbf{6}$ & Risk orientation $\left(\mathrm{X}_{6}\right)$ & $0.179^{*}$ \\
\hline $\mathbf{7}$ & Social participation $\left(\mathrm{X}_{7}\right)$ & 0.021 \\
\hline $\mathbf{8}$ & Mass Media exposure $\left(\mathrm{X}_{8}\right)$ & $0.507 * *$ \\
\hline
\end{tabular}

** Significant at $1 \%$ level significance, $*$ Significant at $5 \%$ level significance

The result shows that the variables experience in Kangayam cattle rearing and mass media exposure are positively and significantly associated with the level of knowledge at $1 \%$ significant level and the variables viz., age, Kangayam cattle herd size and risk orientation are positively associated with knowledge level at 5\% significant level.

The findings of the present study concluded that majority of the respondents belonged to medium socioeconomic status, middle aged, had land holding between 2.5 acres to 5 acres of land and were primarily agriculturist. Majority had $7-10$ years of experience in Kangayam cattle rearing and had medium level of risk orientation and high level of social participation. Majority of the respondents had medium level of knowledge in various domains of vermicompost technology and there is a positive and significant relationship between the knowledge and experience in Kangayam cattle rearing and mass media exposure. Hence, suitable extension programmes should be planned to inculcate the knowledge about the vermicompost technology to increase the compost production in the future farming conditions.

\section{References}

Kharmale, P.R. (2006). Knowledge and adoption of vermicompost technology by the farmers. Unpublished M.Sc. (Ag) Thesis, Marathwada Agricultural University, Parbhni, M.S., India

Lavania, P. and Kumar, D. (2014). Knowledge and attitude of farmers towards vermi compost technology, Barmer. Indian Journal of Extension Education.22: 56-59.

Pagaria, P. (2014). Knowledge and attitude of farmers towards vermicompost technology, Rajasthan. JKV, 3 (1): 4244.

Satya, P. and Dibyanshu, S. (2012). Benefits of organic manure and their preparation techniques. An International Conference on Extension Education in the Perspectives of Advances in Natural Resource Management in Agriculture (NaRMA - IV), Bikaner: proceedings. p.35. 
Vyas L, Bhardwaj LR, Panwar P. (2014). A scale to measure knowledge of tribal women regarding vermiculture technology. Asian Journal of Home Science. 9(1):162-165.

\section{How to cite this article:}

Kavithaa, N.V., N. Vimalrajkumar, C. Manivannan and Manokaran, S. 2020. Assessment of Knowledge Level and Its Determinants amongst Kangayam Cattle Farmers in Vermicomposting. Int.J.Curr.Microbiol.App.Sci. 9(09): 149-154.

doi: https://doi.org/10.20546/ijcmas.2020.909.018 